\title{
Cytokinesis failure and successful multipolar mitoses drive aneuploidy in glioblastoma cells
}

\author{
SERGEJ TELENTSCHAK, MARK SOLIWODA, KLAUS NOHROUDI, \\ KLAUS ADDICKS and FRANZ-JOSEF KLINZ
}

Department I of Anatomy, University of Cologne, D-50931 Cologne, Germany

Received May 20, 2014; Accepted July 22, 2014

DOI: $10.3892 /$ or.2015.3751

\begin{abstract}
Glioblastoma (GB) is the most frequent human brain tumor and is associated with a poor prognosis. Multipolar mitosis and spindles have occasionally been observed in cultured glioblastoma cells and in glioblastoma tissues, but their mode of origin and relevance have remained unclear. In the present study, we investigated a novel GB cell line (SGB4) exhibiting mitotic aberrations and established a functional link between cytokinesis failure, centrosome amplification, multipolar mitosis and aneuploidy in glioblastoma. Long-term live cell imaging showed that $>3 \%$ of mitotic SGB4 cells underwent multipolar mitosis (tripolar $>$ tetrapolar $>$ pentapolar). A significant amount of daugther cells generated by multipolar mitosis were viable and completed several rounds of mitosis. Pedigree analysis of mitotic events revealed that in many cases a bipolar mitosis with failed cytokinesis occurred prior to a multipolar mitosis. Additionally, we observed that SGB4 cells were also able to undergo a bipolar mitosis after failed cytokinesis. Colchicine-induced mitotic arrest and metaphase spreads demonstrated that SGB4 cells had a modal chromosome number of 58 ranging from 23 to 170 . Approximately $82 \%$ of SGB 4 cells were hyperdiploid (47-57 chromosomes) or hypotriploid (58-68 chromosomes). In conclusion, SGB4 cells passed through multipolar cell divisions and generated viable progeny by reductive mitoses. Our results identified cytokinesis failure occurring before and after multipolar or bipolar mitoses as important mechanisms to generate chromosomal heterogeneity in glioblastoma cells.
\end{abstract}

\section{Introduction}

Glioblastoma (GB) is the most malignant type of glioma as well as the most abundant malignant cancer of the adult human

Correspondence to: Dr Sergej Telentschak, Present address, Department of Neurosurgery, University of Cologne, Kerpener Str. 62, D-50937 Cologne, Germany

E-mail: sergej.telentschak@uk-koeln.de

Key words: glioma, multipolar spindles, reductive mitosis, cytokinesis failure, aneuploidy brain. Due to its high malignancy and highly infiltrating growth it is classified by WHO as grade IV astrocytoma. Despite progress in diagnosis, surgery and chemotherapy the median survival time of patients suffering from GB is 15 months (1) and the 5-year survival rate is $4.7 \%$ (2).

Abnormalities of mitoses and chromosomes in cancer tissues were described in the late 1880s and Von Hansemann suggested that cancer cells develop from normal cells due to a tendency to maldistribute chromosomes during mitosis (3). Currently, genomic and/or chromosomal instability are widely accepted as a hallmark of cancer cells (4-6). Systematic karyotyping of various types of cancer revealed that the chromosome number in cancer cells is highly variable ranging from $<46$ to 200 chromosomes (7). It is generally thought that aneuploidy is a driver of tumor evolution. High-grade aneuploidy describes the deviation of many chromosomes from the euploid chromosome number and is based on chromosomal instability (8).

Cytokinesis is the final step in cell division and is characterized by the formation of a contractile ring resulting in a cleavage furrow and eventually a midbridge. At the end of cytokinesis the midbody localized in the middle of the midbridge is cleaved to physically separate the daughter cells. As complex processes such as cytokinesis may fail (9), cytokinetic defects have been suggested to promote tumorigenesis by leading to tetraploidy, supernumerary centrosomes and chromosomal instability $(10,11)$. Polyploidization and aneuploidy constitute early events in the development of many types of cancer (12). In a recent study, Sottoriva et al demonstrated that extensive intratumoral genetic heterogeneity and multiple cell lineages coexist in glioblastoma (13). Besides the assembly of multipolar mitotic spindles, aneuploidy is often caused by errors in chromosome partitioning during mitosis such as weakened mitotic checkpoint signaling, defects in chromosome cohesion or attachment (lagging chromosomes), or even supernumerary centrosomes in bipolar mitotic spindles. A correlation between centrosome amplification and malignant transformation has recently been described for many types of cancer (14). For high-grade gliomas supernumerary centrosomes and increases in the expression of centrosome-related mRNAs have been reported (15). Assessment of the spatial distribution patterns of numerical chromosome aberrations revealed that glioblastoma cells in vivo are characterized by a high mitotic error rate (16). Using combined spindle immunofluorescence analysis and 
fluorescence in situ hybridization, Klein et al reported that the primary T5913 glioma cell line exhibited multipolar spindles in one-third of the investigated cells; however, live cell imaging was not performed (17). Multipolar mitoses were occasionally observed in time lapse recordings of cultured glioblastoma cells, but the fate of daughter cells was not examined (18). We established a novel GB cell line (SGB4) exhibiting cytokinesis failure, multipolar mitoses and a profound heterogeneity in chromosome number. Using time-lapse video analysis we showed that daughter cells produced by multipolar mitosis were often viable and mitotically active. The presented results demonstrated that GB cells are able to use reductive mitoses as a mechanism to generate aneuploidy.

\section{Materials and methods}

Materials. B27, penicillin, streptomycin and L-glutamine were obtained from Invitrogen (Karlsruhe, Germany). DMEM/F12, fetal calf serum (FCS) gold, and Accutase ${ }^{\mathrm{TM}}$ were from PAA (Cölbe, Germany). EGF and bFGF were from Preprotech (Tebu, Offenbach, Germany). Demecolcine solution $\left(\right.$ Colcemid $\left.{ }^{\mathrm{TM}}\right)$ and modified Giemsa stain were obtained from Sigma-Aldrich (Taufkirchen, Germany). Culture dishes (Falcon ${ }^{\circledR}$ ) and nylon meshes were from Becton Dickinson (Franklin Lakes, NJ, USA). Four-well tissue culture plates $\left(\right.$ Nunc $\left.^{\circledR}\right)$ were obtained from Invitrogen (Karlsruhe, Germany). FNC Coating Mix ${ }^{\circledR}$ was obtained from Athena (Baltimore, MD, USA).

Culture of glioblastoma cells. The SGB4 cell line was isolated from the left frontal precentral glioblastoma (classified by WHO as grade IV astrocytoma) of a 52-year-old European woman concurrently suffering from a right frontobasal glioblastoma (WHO grade IV). The patient developed amnesic aphasia and generalized seizure. The suspected diagnosis was made by contrast-enhanced MRI. Two weeks after diagnosis the patient underwent primary tumor extirpation of the right frontal lobe glioblastoma and 10 days later the left frontal lobe glioblastoma was also surgically removed. The diagnosis was confirmed histopathologically as glioblastoma WHO grade IV (left frontal lobe) and glioblastoma with oligodendroglial component WHO grade IV (right frontal lobe). Subsequently the patient underwent concomitant radiochemotherapy followed by sequential chemotherapy with temozolomide.

The use of human material in this study was approved by the local ethics committee and conforms to the World Medical Association Declaration of Helsinki. The patient signed an informed consent form prior to surgery. A fresh GB sample was kindly provided by Professor Jürgen Hampl (Department of Neurosurgery, University of Cologne). The tissue was cut into small sections and cells were released by mechanical dissociation. Tissue fragments were subsequently removed by filtration through a $70-\mu$ m nylon mesh and the cells were seeded in culture dishes at a density of 100,000 cells $/ \mathrm{ml}$ medium. The culture medium (neurosphere medium) consisted of DMEM/F12 supplemented with $2 \mathrm{mM}$ L-Glutamine, $100 \mathrm{U} / \mathrm{ml}$ penicillin, $100 \mu \mathrm{g} / \mathrm{ml}$ streptomycin, $2 \%$ (v/v) B27, $20 \mathrm{ng} / \mathrm{ml}$ EGF and $20 \mathrm{ng} / \mathrm{ml} \mathrm{bFGF}$. Between days 3 and 5 newly formed spheres were separated from cell
Table I. Frequency of different mitotic events in SGB4 cells in an early passage (no. 7) and in a late passage (no. 30).

\begin{tabular}{lcc}
\hline $\begin{array}{l}\text { Types } \\
\text { of mitotic events }\end{array}$ & $\begin{array}{c}\text { In passage no. } 7 \\
\mathrm{n}(\%)\end{array}$ & $\begin{array}{c}\text { In passage no. 30 } \\
\mathrm{n}(\%)\end{array}$ \\
\hline $\begin{array}{l}\text { Total number of } \\
\text { observed mitoses }\end{array}$ & $973(100)$ & $1,651(100)$ \\
$\begin{array}{l}\text { Bipolar mitoses } \\
\text { Total number of }\end{array}$ & $940(96.6)$ & $1,593(96.5)$ \\
multipolar mitoses & $33(3.4)$ & $58(3.5)$ \\
$\begin{array}{l}\text { Tripolar mitoses } \\
\text { Tetrapolar mitoses }\end{array}$ & $17(1.7)$ & $37(2.2)$ \\
Mitoses of higher & $8(0.8)$ & $12(0.7)$ \\
or undefined polarity & $8(0.8)$ & $9(0.5)$ \\
\hline
\end{tabular}

andicated by the number of spindle poles observed in the anaphase.

debris and blood cells by filtration through a $40-\mu \mathrm{m}$ nylon mesh. The medium was changed twice a week and spheres were split by mechanical dissociation when they reached an average minimal diameter of $\sim 300 \mu \mathrm{m}$.

To enable microscopic observation of the mitotic events SGB4 cells from spheres were cultured as adherent cells in monolayer culture under low serum conditions. The culture medium (monolayer medium) consisted of DMEM/F12 supplemented with $2 \mathrm{mM}$ L-Glutamine, $100 \mathrm{U} / \mathrm{ml}$ penicillin, $100 \mu \mathrm{g} / \mathrm{ml}$ streptomycin, $2 \%$ (v/v) B27, and 1\% (v/v) FCS. Prior to reaching confluency, the cells were detached using Accutase $^{\mathrm{TM}}$ and replated at a density of 5,000 cells $/ \mathrm{cm}^{2}$.

Long-term live cell imaging. For live cell imaging passage nos. 7 and 30 were used. Twenty-four hours after plating, SGB4 cells in monolayer culture were observed for up to 14 days using a vital imaging system (Zeiss, Oberkochem, Germany). Images were captured every $5 \mathrm{~min}$. The medium was changed carefully every 2 days.

Chromosome spreading. Chromosome spreads were performed on cells in passage no. 7. SGB4 cells were treated with $0.05 \mu \mathrm{g} / \mathrm{ml}$ Colcemid ${ }^{\mathrm{TM}}$ for $3 \mathrm{~h}$. After hypotonic lysis SGB4 cells were fixed for $20 \mathrm{~min}$ in ice-cold methanol: acetic acid (3:1). Metaphase spreads were produced on glass slides and chromosomes were stained with modified Giemsa stain. After images were captured chromosome numbers of 95 metaphases were counted.

\section{Results}

Mitotic events and multipolar mitoses. To analyze mitotic events in the SGB4 cell line we used long-term time-lapse video microscopy. Using this system we were able to track the fate of progeny from multipolar mitosis and of the cells that subsequently underwent multipolar mitosis. Based on these records, we analyzed mitotic events and viability in SGB4 cells. Furthermore, we performed these surveys in an early passage no. 7 (973 mitoses analyzed) and in a later passage 

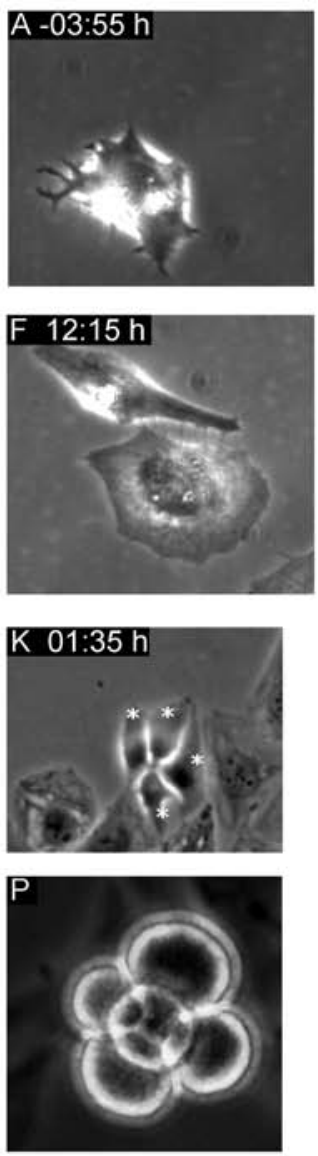
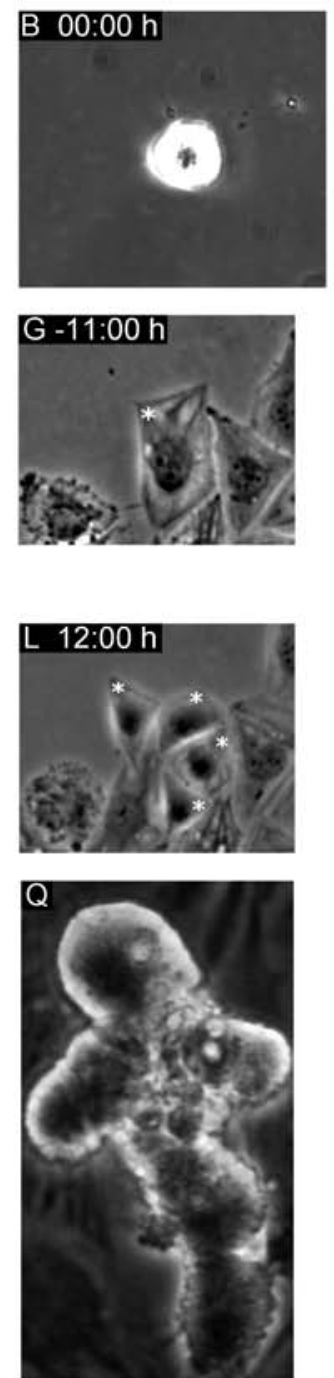
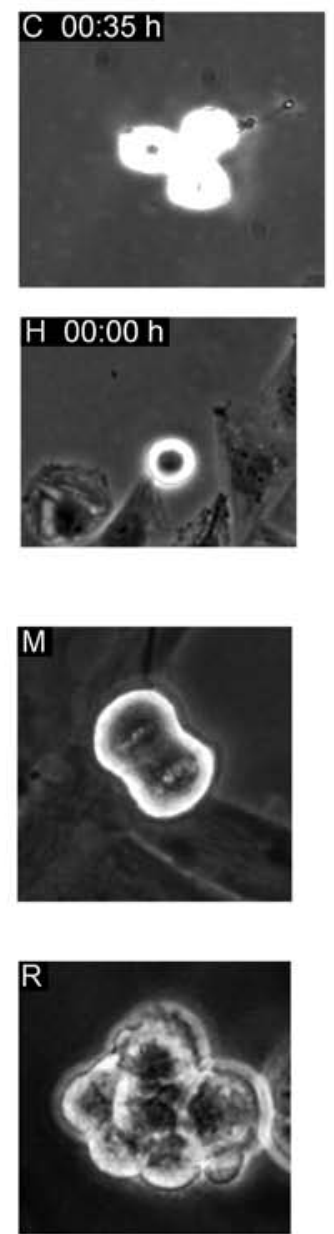
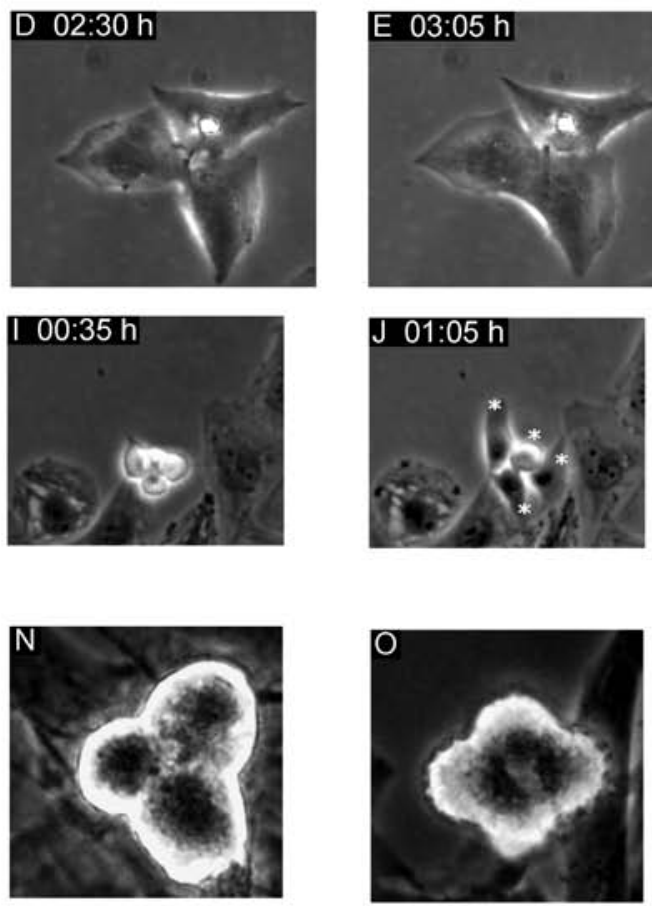

Figure 1. Multipolar mitoses of SGB4 cells. (A-F) A time-lapse sequence showing a tripolar mitosis with failed cytokinesis that resulted in a refusion of two daughter cells: (B) metaphase, (C) tripolar anaphase, (D) tripolar telophase, (E) cytokinesis failure and (F) refusion of lower two daughter cells. Magnification, x100. (G-L) A time-lapse sequence showing a tetrapolar mitosis resulting in 4 progenies: (H) metaphase, (I) tetrapolar anaphase, (J) tetrapolar telophase, (K) successful cytokinesis, (L) four independent daughter cells (marked white asterisks). Magnification, x100. (M-R) Phase-contrast images of mitotic SGB4 cells: (M) bipolar, (N) tripolar, (O) tetrapolar, (P) pentapolar, (Q) undefined higher polarity, (R) presumably octaploid. Magnification, x320.

no. 30 (1,651 mitoses analyzed). By comparing the results we examined whether changes in the frequency of mitotic events occurred within the 9-month time interval between early and late passage number.

The rate of multipolar mitoses was $\sim 3.5 \%$ in passage nos. 7 and 30. The predominant type of multipolar mitoses were tripolar mitoses (passage no. 7: $1.7 \%$ and passage no. 30: $2.2 \%$ ) followed by less frequent tetrapolar mitoses (passage no. 7: $0,8 \%$ and passage no. 30: $0.7 \%$ ) and rare mitoses of higher or undefined polarity (Table I; Fig. 1A-R).

The polarity of multipolar anaphases differed often from the final number of progenies. Progenies frequently underwent a refusion due to failed cytokinesis. Such refusion events occurred randomly in anaphase, telophase or even within 4 days after the generation of the multipolar metaphase plate and resulted in a random number of daughter cells. Tripolar mitoses eventually yielded one, two or three progenies in comparable amounts. Progenies of tetrapolar mitoses ranged from one to four and showed a strong tendency to yield one or two daughter cells. Mitoses of higher and undefined polarity yielded up to four progenies, however, in the majority of cases only one daughter cell was observed (Table II, Fig. 1A-L).

Fate of progenies generated by multipolar mitoses. Due to limitations of long-term video microscopy (for instance, increasing cell density due to cell proliferation) cultured cells were observed for up to 14 days. For live-cell imaging we plated SGB4 cells in culture dishes with a density of 15,000 cells $/ \mathrm{cm}^{2}$ and started the time-lapse recording of a region within the culture dish containing 70-100 cells. After 5 days we had observed an adequate number of multipolar mitoses to follow up the progenies for the remaining 9 days. In this way we were able to draw up a pedigree for each observed multipolar mitosis. The rate of multipolar mitoses with proliferating daughter cells in passage no. 7 accounted for $16.7 \%$ of all multipolar mitoses and increased to $53.3 \%$ in passage no. 30, with multipolar mitoses with bipolar and multipolar dividing progenies at a ratio of 2:3 (Table III).

We observed that in passage 30 the daughter cells of a multipolar mitosis underwent a bipolar mitosis $(91.7 \%)$, if no 
Table II. Impact of cytokinesis failure at the end of multipolar mitoses on the progeny number of SGB4 cells: A comparison of the number of spindle poles in anaphase with the final progeny number.

\begin{tabular}{|c|c|c|}
\hline $\begin{array}{l}\text { Type of } \\
\text { multipolar mitosis }\end{array}$ & $\begin{array}{l}\text { passage no. } 7 \\
\mathrm{n}(\%)\end{array}$ & $\begin{array}{c}\text { In passage no. } 3 \\
\mathrm{n}(\%)\end{array}$ \\
\hline $\begin{array}{l}\text { Total number } \\
\text { of multipolar mitoses }\end{array}$ & $32(100)$ & $57(100)$ \\
\hline Tripolar mitoses (3pM) & $16(50)$ & $36(63.2)$ \\
\hline $\begin{array}{l}\text { Three spindle poles } \\
\text { resulting in } 1 \text { daughter cell } \\
\text { ( } 3 \mathrm{P} \text { to } 1 \mathrm{D})\end{array}$ & $5(15.6)$ & $12(21)$ \\
\hline $\begin{array}{l}\text { Three spindle poles } \\
\text { resulting in } 2 \text { daughter cells } \\
\text { ( } 3 \mathrm{P} \text { to } 2 \mathrm{D} \text { ) }\end{array}$ & $6(18.8)$ & $13(22.8)$ \\
\hline $\begin{array}{l}\text { Three spindle poles } \\
\text { resulting in } 3 \text { daughter cells } \\
\text { (3P to } 3 \mathrm{D})\end{array}$ & $5(15.6)$ & $11(19.3)$ \\
\hline Tetrapolar mitoses (4pM) & $8(25)$ & $12(21.1)$ \\
\hline $\begin{array}{l}\text { Four spindle poles } \\
\text { resulting in } 1 \text { daughter cell } \\
\text { (4P to } 1 \mathrm{D})\end{array}$ & $2(6.3)$ & $4(7)$ \\
\hline $\begin{array}{l}\text { Four spindle poles } \\
\text { resulting in } 2 \text { daughter cells } \\
\text { ( } 4 \mathrm{P} \text { to } 2 \mathrm{D})\end{array}$ & $3(9.4)$ & $6(10.5)$ \\
\hline $\begin{array}{l}\text { Four spindle poles } \\
\text { resulting in } 3 \text { daughter cells } \\
\text { ( } 4 \mathrm{P} \text { to } 3 \mathrm{D})\end{array}$ & $1(3.1)$ & $2(3.5)$ \\
\hline $\begin{array}{l}\text { Four spindle poles } \\
\text { resulting in } 4 \text { daughter cells } \\
(4 \mathrm{P} \text { to } 4 \mathrm{D})\end{array}$ & $2(6.3)$ & - \\
\hline $\begin{array}{l}\text { Mitoses of higher or } \\
\text { undefined polarity }(\mathrm{XpM})\end{array}$ & $8(25)$ & $9(15.8)$ \\
\hline $\begin{array}{l}\text { All spindle poles resulting } \\
\text { in } 1 \text { daughter cell } \\
\text { (XP to } 1 \mathrm{D})\end{array}$ & $5(15.6)$ & $5(8.8)$ \\
\hline $\begin{array}{l}\text { All spindle poles resulting } \\
\text { in } 2 \text { daughter cells } \\
\text { (XP to } 2 \mathrm{D})\end{array}$ & $2(6.3)$ & $1(1.8)$ \\
\hline $\begin{array}{l}\text { All spindle poles resulting } \\
\text { in } 3 \text { daughter cells } \\
\text { (XP to } 3 \mathrm{D})\end{array}$ & $1(3.1)$ & $2(3.5)$ \\
\hline $\begin{array}{l}\text { All spindle poles resulting } \\
\text { in } 4 \text { daughter cells (XP to } 4 \mathrm{D} \text { ) }\end{array}$ & - & $1(1.8)$ \\
\hline
\end{tabular}

Cytokinesis failure occurred within 4 days after the multipolar metaphase plate. Therefore, in this analysis we included only those multipolar mitoses that were observed for at least 4 additional days after multipolar metaphase plate.

refusion with other daughter cells occurred. In case of a refusion, exiting daughter cells underwent a multipolar mitosis in $72.2 \%$ of examined events (Table IV). This ratio is expected because cytokinesis failure-induced refusion resulted in the
Table III. Frequency of multipolar mitoses (MPM) with progenies in an early passage (no. 7) and in a late passage (no. 30) of SGB4 cells.

\begin{tabular}{lcc}
\hline $\begin{array}{l}\text { Types } \\
\text { of mitotic events }\end{array}$ & $\begin{array}{c}\text { In passage no. } 7 \\
\mathrm{n}(\%)\end{array}$ & $\begin{array}{c}\text { In passage no. 30 } \\
\mathrm{n}(\%)\end{array}$ \\
\hline $\begin{array}{l}\text { Total number } \\
\text { of MPM }\end{array}$ & $30(100)$ & $45(100)$ \\
$\begin{array}{l}\text { MPM with } \\
\text { proliferating progenies }\end{array}$ & $5(16.7)$ & $24(53.3)$ \\
$\begin{array}{l}\text { MPM with bipolar } \\
\text { dividing progenies }\end{array}$ & $2(6.7)$ & $9(20)$ \\
$\begin{array}{l}\text { MPM with multipolar } \\
\text { dividing progenies }\end{array}$ & $3(10)$ & $14(31.1)$ \\
$\begin{array}{l}\text { MPM with bipolar and } \\
\text { multipolar dividing } \\
\text { progenies }\end{array}$ & - & $1(2.2)$ \\
\hline
\end{tabular}

Only those multipolar mitoses where the progenies for at least 9 days after multipolar metaphase plate were observed, were included.

polyploidy of daughter cells that was subsequently reduced by multipolar mitosis.

The percentage of non-viable progenies of multipolar mitoses decreased from $31 \%$ in passage no. 7 to $24.1 \%$ in passage no. 30. Progenies that underwent a refusion with sister cells subsequent to multipolar mitosis (in terms of cytokinesis failure), were distinctly less non-viable than those that did not undergo any refusion (without cytokinesis failure; Table IV).

Mitotic history of cells. To clarify the origin of cells undergoing multipolar mitoses the videomicroscopic records were investigated retrospectively. As presented in Table $\mathrm{V}$ the mitotic history of cells undergoing multipolar mitosis corresponded to one of the following 3 different scenarios: i) Over half of the multipolar dividing cells $(66.7 \%$ in passage no. 7 and $53.6 \%$ in passage no. 30) arose through the cytokinesis failure of a preceding bipolar mitosis with a subsequent refusion event of two daughter cells (Fig. 2A-M). ii) Approximately one-fifth of multipolar dividing cells $(20 \%$ of cases in passage no. 7 and $17.9 \%$ in passage no. 30) arose from an apparently regular bipolar mitosis or after a sequence of bipolar mitoses, with an initial cytokinesis failure-induced refusion event being observed in some cases (Fig. 2N-Z). iii) After long-term passaging, we observed an increasing number of events $(13.3 \%$ of cases in passage no. 7 and $28.6 \%$ in passage no. 30) where a progeny of a multipolar mitosis underwent a subsequent multipolar cell division.

Chromosome numbers in SGB4 cells. We expected substantial aneuploidy as a result of failed cytokinesis and multipolar mitoses in cultured SGB4 cells. To investigate chromosome numbers we treated SGB4 in passage no. 7 cells with Colcemid to increase the yield of metaphase spreads. An analysis of chromosome numbers in the metaphase spreads was performed by light microscopy. The modal chromosome 
Table IV. Fate of progenies generated by multipolar mitoses (MPM) in an early passage (no. 7) and in a late passage (no. 30) of SGB4 cells.

Outcome of progenies generated through MPM

Total number of long-term observed progenies of MPM

Total number of proliferating progenies of MPM

Bipolar dividing progenies of MPM ${ }^{\mathrm{a}}$

Multipolar dividing progenies of $\mathrm{MPM}^{\mathrm{b}}$

Viable but non-proliferating progenies of MPM

Non-viable progenies of MPM $^{\mathrm{c}}$

$$
\begin{gathered}
\text { In passage no. } 7 \\
\mathrm{n}(\%)
\end{gathered}
$$

$$
\begin{gathered}
58(100) \\
6(10.3) \\
2(3.4) \\
4(6.9) \\
34(58.6) \\
18(31)
\end{gathered}
$$

In passage no. 30 $\mathrm{n}(\%)$

${ }^{a}$ Fifty per cent ( 1 of 2 ) of bipolar dividing progenies generated by multipolar mitoses in passage no. 7 and $91.7 \%$ (11 of 12$)$ in passage no. 30 underwent no refusion with their sister cells; ${ }^{\text {b } 75 \% ~(3 ~ o f ~ 4) ~ o f ~ m u l t i p o l a r ~ d i v i d i n g ~ p r o g e n i e s ~ g e n e r a t e d ~ b y ~ m u l t i p o l a r ~ m i t o s e s ~ i n ~ p a s s a g e ~ n o . ~} 7$ and $72.2 \%$ (13 of 18) in passage no. 30 underwent a refusion with their sister cells; ${ }^{\mathrm{c}} 66.7 \%$ (12 of 18 ) of non-viable progenies generated by multipolar mitoses in passage no. 7 and $90 \%$ (18 of 20) in passage no. 30 did not undergo a refusion with their sister cells subsequent to multipolar mitosis.
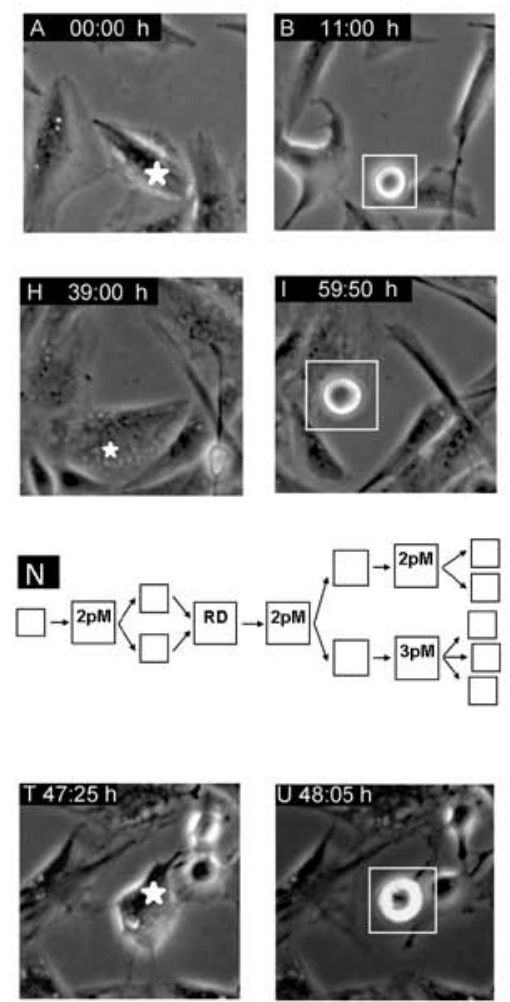
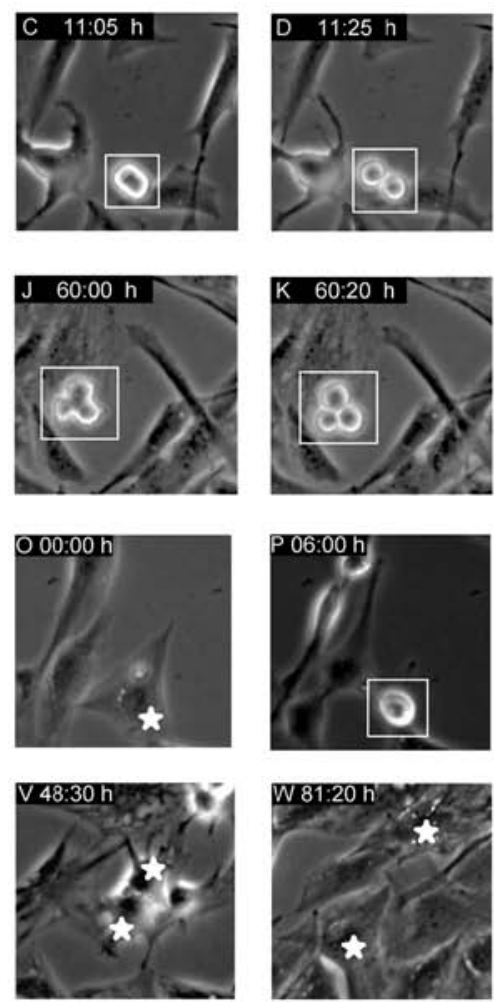
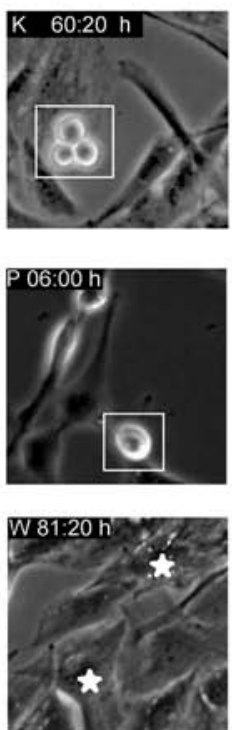
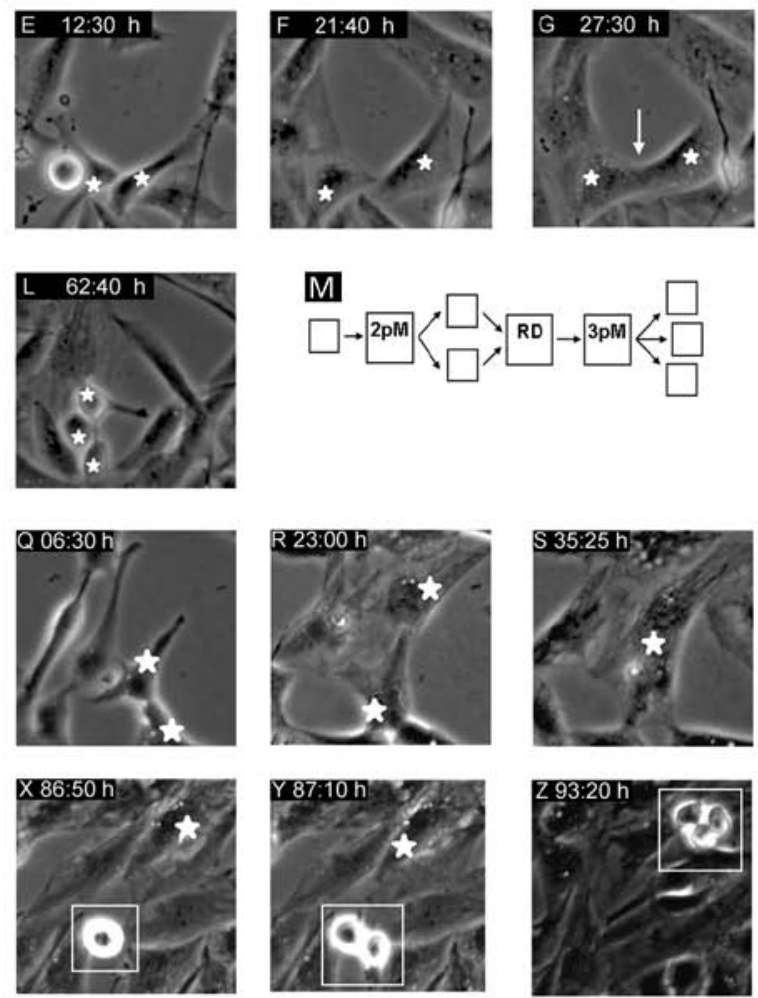

Figure 2. Cytokinesis failure is followed by multipolar or bipolar mitosis in SGB4 cells. (A-H) A time-lapse sequence showing a bipolar mitosis with failed cytokinesis, resulting in the refusion of daughter cells: (B) bipolar metaphase, (C) bipolar anaphase, (D) bipolar telophase (marked by white squares). (E-H) The two daughter cells (marked by white asterisks) persisted for many hours without any obvious interaction prior to initiation of their refusion (marked by white arrow). (I-L) Subsequently, the refusion-derived cell underwent a tripolar mitosis (marked by white squares) with three viable daughter cells (marked by white asterisks): (I) tripolar metaphase, (J) tripolar anaphase, (K) tripolar telophase, (L) three daughter cells in cytokinesis. Magnification, x100. (M) A pedigree reflecting the time-lapse sequence shown in A-L (2pM, bipolar mitosis; RD, refusion-derived daughter cell, 3pM, tripolar mitosis. (N) A pedigree reflecting the time-lapse sequence presented in O-Z. (O-S) A time-lapse sequence showing a bipolar mitosis with failed cytokinesis, resulting in a refusion of daughter cells (marked by white asterisks and squares). (T-V) Subsequently, the refusion-derived daughter cell underwent a new bipolar mitosis resulting in two progenies. (W-Z) The lower daughter cell underwent bipolar mitosis (marked by white square), while the upper daughter cell underwent tripolar mitosis (marked by white asterisk). Magnification, x100.

number was 58 ranging from 23 (haploid) to 170 (hyperheptaploid) (Fig. 3A-E). The majority of SGB4 cells (45.3\%) were hypotriploid with $58-68$ chromosomes followed by $36.8 \%$ of hyperdiploid SGB4 cells with 47-57 chromosomes (Fig. 3B). Approximately $8 \%$ had $>100$ chromosomes (Fig. 3A and E).

\section{Discussion}

Cytokinesis failure and multipolar mitosis are mechanisms that lead to aneuploidy and were observed in cultured cells from many types of cancer. Since amplifications of centro- 


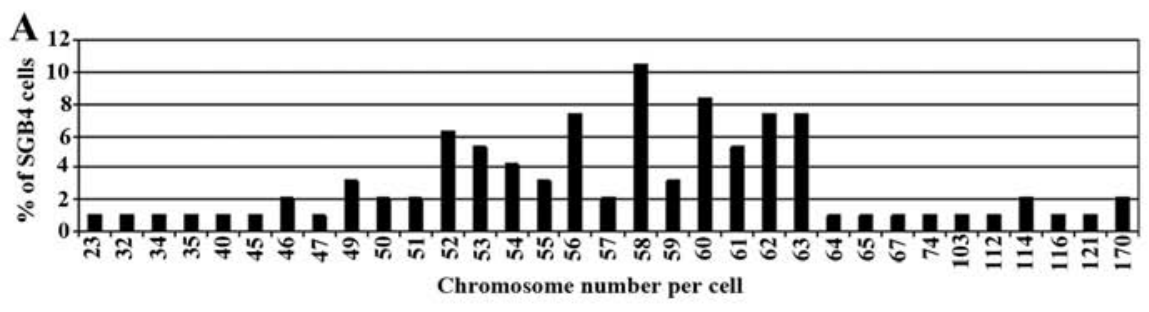

C

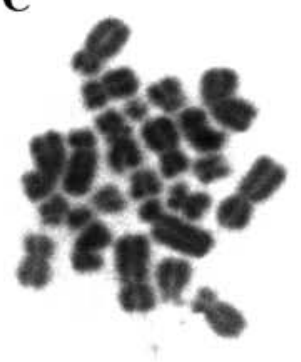

D

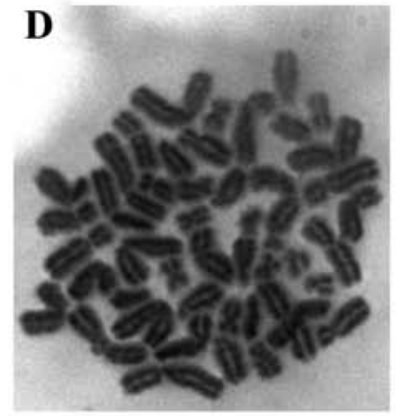

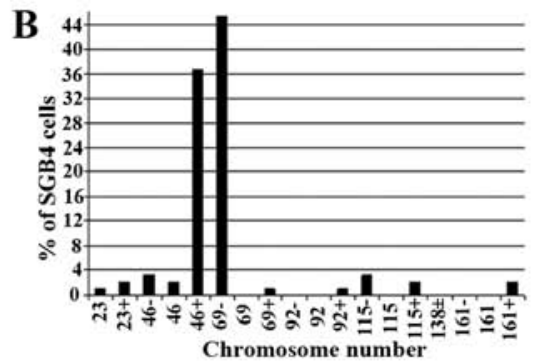

Chromosome number

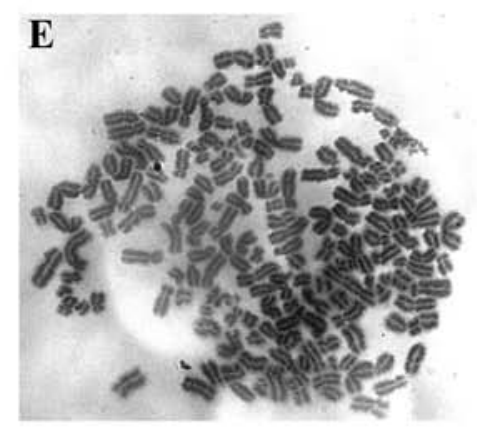

Figure 3. Chromosome number in SGB4 cells based on metaphase chromosome spreading. (A) Percentage of SGB4 cells with respective numbers of chromosomes: modal chromosome number $=58$; median chromosome number $=58$; mean chromosome number $=60.5$. (B) Summary of chromosome numbers according to ISCN (2013) (36): haploidy (23), hyperhaploidy $(23+)=24-34$, hypodiploidy $(46-)=35-45$, diploidy (46), hyperdiploidy $(46+)=47-57$, hypotriploidy $(69-)=58-68$, triploidy (69), hypertriploidy $(69+)=70-80$, hypotetraploidy $(92-)=81-91$, tetraploidy (92), hypertetraploidy $(92+)=93-103$, hypopentaploidy $(115-)=104-114$, pentaploidy (115), hyperpentaploidy $(115+)=116-126$, hypohexaploidy $(138-)=127-137$, hexaploidy (138), hyperhexaploidy $(138+)=139-149$, hypopentaploidy $(161-)=150-160$, heptaploidy (161), hyperheptaploidy $(161+)=162-172$. An example of metaphase cells with (C) 23 , (D) 46 and (E) 170 chromosomes is shown.

Table V. Origin of SGB 4 cells that underwent a multipolar mitosis (MPM) in an early passage (no. 7) and in a late passage (no. 30).

\begin{tabular}{|c|c|c|}
\hline $\begin{array}{l}\text { Origin of } \\
\text { multipolar } \\
\text { dividing cells }\end{array}$ & $\begin{array}{c}\text { In passage no. } 7 \\
\mathrm{n}(\%)\end{array}$ & $\begin{array}{c}\text { In passage no. } 30 \\
\mathrm{n}(\%)\end{array}$ \\
\hline $\begin{array}{l}\text { Total number } \\
\text { of observed cells }\end{array}$ & $30(100)$ & $56(100)$ \\
\hline $\begin{array}{l}\text { Genesis through } \\
\text { cytokinesis failure } \\
\text { subsequent to } \\
\text { bipolar mitosis } \\
\text { (Fig. 2A-M) }\end{array}$ & $20(66.7)$ & $30(53.6)$ \\
\hline $\begin{array}{l}\text { Genesis through } \\
\text { cytokinesis failure } \\
\text { with one or several } \\
\text { subsequent } \\
\text { bipolar mitoses } \\
\text { prior to an MPM } \\
\text { (Fig. 2N-Z) }\end{array}$ & $6(20)$ & $10(17.9)$ \\
\hline $\begin{array}{l}\text { Origin from a progeny } \\
\text { of an MPM }\end{array}$ & $4(13.3)$ & $16(28.6)$ \\
\hline
\end{tabular}

somes and multipolar spindles have also been observed in different cancer tissues, it is reasonable to assume that these mechanisms are linked to aneuploidy and cancer development in vivo. Using a combination of live cell imaging and fluorescence in situ hybridization, Yang et al reported that for cultured colorectal cancer cells multipolar divisions occurred in mononucleated and binucleated parental cells resulting in karyotype variation in daughter cells (19). On the basis of a systematic study of The Mittelman Database (15,000 karyotypes from 62 cancer classes) and the NCI and NCBI's SKY/M-FISH and CGH database (1,084 samples obtained by CGH) in terms of chromosomal aberrations, Ozery-Flato et al suggested that aneuploid cancer cells may use extra chromosome gain or loss events to restore a balance in their altered protein ratios, needed for maintaining their cellular fitness (20). Although almost all mammals are diploid, specialized mammalian cells present whole-genome duplications as part of normal development (12). Additionally, polyploid mouse hepatocytes use multipolar mitoses as a physiological mechanism for somatic ploidy reversal and generation of genetic diversity (21).

Using long-term live cell imaging, Ganem et al showed that for a number of cancer cell lines, cells with multiple centrosomes rarely underwent multipolar divisions and that the progeny of these mitoses were typically non-viable (22). The authors concluded that multipolar mitoses cannot explain observed rates of chromosomal instability. Instead, Ganem et al demonstrated that cells with extra centrosomes routinely underwent bipolar mitosis, but exhibited an increased frequency of lagging chromosomes during anaphase (22). Using colorectal cancer cell lines Silkworth et al reported that a bipolar mitosis with lagging chromosomes is often preceded by the initiation of a multipolar mitosis in combination with centrosome coalescence and thereby reduction of the spindle number (23). 
Clustering as well as the inactivation of extra centrosomes are important mechanisms to induce bipolar mitoses in a variety of cultured cancer cell lines (24). Our long-term time-lapse video microscopy analysis of SGB4 cells demonstrated that successful multipolar mitosis occurred in cultured GB cells, suggesting that clustering or inactivation of centrosomes was not able to inhibit multipolar mitosis of SGB4 cells.

To the best of our knowledge, this is the first study to provide a detailed long-term analysis of mitotic events in a brain cancer cell line. Mitotic cells of the newly established glioblastoma SGB4 cell line frequently exhibited failed cytokinesis. Daughter cells initially generated by bipolar mitosis frequently underwent a reunion occurring immediately after an apparently successful cell division or after incomplete cytokinesis. The cleavage furrow developed normally and the two daughter cells separated from each other, but presumably remained connected for a certain period of time by a narrow cytoplasmic bridge prior to refusion. Similar refusion processes were observed in cultured HeLa cells, which occurred without the addition of any drugs (25).

In addition, we observed that multipolar mitoses were often preceded by cytokinesis failure. Failed cytokinesis and subsequent fusion of daughter cells is expected to result in increased numbers of chromosomes and centrosomes. Polyploidy and supernumerary centrosomes are prerequisites for the cells to undergo successful multipolar mitosis. In contrast to other studies using human cancer cell lines (22) multipolar mitoses in SGB4 cells often resulted in viable daughter cells that were able to complete subsequent mitoses.

Accumulating evidence suggests that several types of non-brain cancer cells with extra centrosomes avoid mitotic catastrophe and cell death (as a consequence of multipolar mitosis) by clustering their extra centrosomes and switching to a bipolar mitosis (26). In accordance with this finding, pharmacological inhibition of centrosome clustering promises to selectively target tumor cells with extra centrosomes. Our results suggest that this strategy may not be useful for glioblastoma cells.

Several mechanisms for the generation of single or multiple whole-chromosome gains have been discussed. As summarized in the review by Gisselsson, available data strongly argue against complete multipolar mitoses as a predominant mechanism in cancer (27). Results of a recent study, however, demonstrated that multipolar mitosis followed by incomplete cytokinesis results in the generation of trisomies (28). In our experiments using GB cancer cells we observed multipolar mitoses that were followed by failed cytokinesis. In addition, our pedigree analysis revealed that failed cytokinesis prior to successful multipolar mitosis is a frequent route for the studied GB cell line and may be an additional mechanism to generate aneuploidy. Cytokinesis failure is expected to result in multinucleated cells. Using confocal microscopy we observed that SGB4 cells often revealed multiple nuclei with irregular structure (pleomorphic nuclei) (data not shown). As pleomorphic nuclei are a well-known characteristic of glioblastoma cells in vivo we hypothesize that they are caused by cytokinesis failure events similar to those observed in SGB4.

Since the replication of polyploid DNA is time- and energy-consuming, multipolar divisions can be considered as a strategy to reduce energy consumption and increase the prolif- eration rate of cancer cells. Our results elucidate multipolar mitoses as a strategy to reduce ploidy and generate genetic heterogeneity of GB cells.

The chromosome number of GB cells in short- or longterm cultures has been extensively studied and chromosome numbers ranging from 23 to 160 have been reported (29-34). However, it should be noted, that in most cases chromosome numbers of cultured GB cells were in the hyperdiploid range. The modal chromosome number of SGB4 was 58 ranging from 23 (haploid) to 170 (hyperheptaploid). Our finding that many SGB4 cells show high-grade aneuploidy is in agreement with observed multipolar mitoses resulting in viable daughter cells.

Gisselsson et al used immunofluorescence analysis and fluorescence in situ hybridization to study multipolar mitoses of the WiT49 cell line derived from an anaplastic Wilms tumor and the SW480 cell line derived from a colorectal carcinoma (35). The authors reported that multipolar mitoses led to a highly variable chromosome segregation and DNA content of daughter cells. However, the proliferation capacity of daughter cells was not examined in this study. The observed wide variation in the chromosome number confirms our finding that SGB4 cells use multipolar mitosis as a mechanism to reduce ploidy (reductive mitosis). Our results show that cytokinesis failure and multipolar mitosis are able to drive aneuploidy and tumorigenesis in glioblastoma. Detailed studies are needed to study the abundance of multipolar mitoses in GB tissues and to demonstrate a correlation with the prognosis of GB patients.

\section{Acknowledgements}

This study was supported by a grant from The Maria PeschStiftung. We thank Jolanta Kozlowski, Eveline Janssen and Christian Hoffman for the expert technical assistance.

\section{References}

1. Stupp R, Mason WP, van den Bent MJ, Weller M, Fisher B, Taphoorn MJ, Belanger K, Brandes AA, Marosi C, Bogdahn U, Curschmann J, Janzer RC, Ludwin SK, Gorlia T, Allgeier A, Lacombe D, Cairncross JG, Eisenhauer E and Mirimanoff RO: Radiotherapy plus concomitant and adjuvant temozolomide for glioblastoma. N Engl J Med 352: 987-996, 2005.

2. Central Brain Tumor Registry of the United States (CBTRUS) Statistical Report (2012). Primary Brain and Central Nervous System Tumors Diagnosed in the United States in 2004-2008. http://www. cbtrus.org/2012-NPCR-SEER/CBTRUS_Report_2004-2008_. Accessed March 23, 2012.

3. Von Hansemann D: Ueber asymmetrische Zellteilung in Epithelkrebsen und deren biologische Bedeutung. Virchows Arch Path J Anat 119: 299-326, (1890)

4. Thompson SL and Compton DA: Chromosomes and cancer cells. Chromosome Res 19: 433-444, 2011.

5. Janssen A and Medema RH: Genetic instability: tipping the balance. Oncogene: Dec 17, 2012 (Epub ahead of print). doi: 10.1038/onc.2012.576.

6. Gordon DJ, Resio B and Pellman D: Causes and consequences of aneuploidy in cancer. Nat Rev Genet 13: 189-203, 2012.

7. Storchova $Z$ and Kuffer C: The consequences of tetraploidy and aneuploidy. J Cell Sci 121: 3859-3866, 2008.

8. Pfau SJ and Amon A: Chromosomal instability and aneuploidy in cancer from yeast to man. EMBO Rep 13: 515-527, 2012.

9. Normand G and King RW: Understanding cytokinesis failure. Adv Exp Med Biol 676: 27-55, 2010.

10. Sagona AP and Stenmark H: Cytokinesis and cancer. FEBS Lett 584: 2652-2661, 2010.

11. Lacroix B and Maddox AS: Cytokinesis, ploidy and aneuploidy. J Pathol 226: 338-351, 2012 
12. Davoli $\mathrm{T}$ and de Lange $\mathrm{T}$ : The causes and consequences of polyploidy in normal development and cancer. Annu Rev Cell Dev Biol 27: 585-610, 2011.

13. Sottoriva A, Spiteri I, Piccirillo SG, Touloumis A, Collins VP, Marioni JC, Curtis C, Watts C and Tavaré S: Intratumor heterogeneity in human glioblastoma reflects cancer evolutionary dynamics. Proc Natl Acad Sci USA 110: 4009-4014, 2013.

14. Chan JY: A clinical overview of centrosome amplification in human cancers. Int J Biol Sci 7: 1122-1144, 2011.

15. Loh JK, Lieu AS, Chou CH, Lin FY, Wu CH, Howng SL, Chio CC and Hong YR: Differential expression of centrosomal proteins at different stages of human glioma. BMC Cancer 10: 268, 2010.

16. Loeper S, Romeike BF, Heckmann N, Jung V, Henn W, Feiden W, Zang KD and Urbschat S: Frequent mitotic errors in tumor cells of genetically micro-heterogeneous glioblastomas. Cytogenet Cell Genet 94: 1-8, 2001.

17. Klein A, Zang KD, Steudel WI and Urbschat S: Different mechanisms of mitotic instability in cancer cell lines. Int J Oncol 29: 1389-1396, 2006.

18. Hegedüs B, Czirók A, Fazekas I, B'abel T, Madar'asz E and Vicsek T: Locomotion and proliferation of glioblastoma cells in vitro: statistical evaluation of videomicroscopic observations. J Neurosurg 92: 428-434, 2000.

19. Yang C, Shi X, Huang Y, Zhang Z, Cooke HJ, Wang M and Shi Q: Rapid proliferation of daughter cells lacking particular chromosomes due to multipolar mitosis promotes clonal evolution in colorectal cancer cells. Cell Cycle 11: 2650-2659, 2012.

20. Ozery-Flato M, Linhart C, Trakhtenbrot L, Izraeli S and Shamir R: Large-scale analysis of chromosomal aberrations in cancer karyotypes reveals two distinct paths to aneuploidy. Genome Biol 12: R61, 2011.

21. Duncan AW, Taylor MH, Hickey RD, Hanlon Newell AE, Lenzi ML, Olson SB, Finegold MJ and Grompe M: The ploidy conveyor of mature hepatocytes as a source of genetic variation. Nature 467: 707-710, 2010.

22. Ganem NJ, Godinho SA and Pellman D: A mechanism linking extra centrosomes to chromosomal instability. Nature 460 : 278-282, 2009.

23. Silkworth WT, Nardi IK, Scholl LM and Cimini D: Multipolar spindle pole coalescence is a major source of kinetochore misattachment and chromosome mis-segregation in cancer cells. PLoS One 4: e65641, 2009.

24. Marthiens V, Piel M and Basto R: Never tear us apart - the importance of centrosome clustering. J Cell Sci 125: 3281-3292, 2012.
25. Moorhead PS and Hsu TC: Cytologic studies of HeLa, a strain of human cervical carcinoma. III. Durations and characteristics of the mitotic phases. J Natl Cancer Inst 16: 1047-1066, 1956.

26. Krämer A, Maier B and Bartek J: Centrosome clustering and chromosomal (in)stability: a matter of life and death. Mol Oncol 5: 324-335, 2011.

27. Gisselsson D: Mechanisms of whole chromosome gains in tumors - many answers to a simple question. Cytogenet Genome Res 133: 190-201, 2011

28. Gisselsson D, Jin Y, Lindgren D, Persson J, Gisselsson L, Hanks S, Sehic D, Mengelbier LH, Øra I, Rahman N, Mertens F, Mitelman F and Mandahl N: Generation of trisomies in cancer cells by multipolar mitosis and incomplete cytokinesis. Proc Natl Acad Sci USA 107: 20489-20493, 2010.

29. Bigner SH, Mark J, Burger PC, Mahaley MS Jr, Bullard DE, Muhlbaier LH and Bigner DD: Specific chromosomal abnormalities in malignant human gliomas. Cancer Res 48: 405-411, 1988.

30. Thiel G, Losanowa T, Kintzel D, Nisch G, Martin H, Vorpahl K and Witkowski R: Karyotypes in 90 human gliomas. Cancer Genet Cytogenet 58: 109-120, 1992.

31. Westphal M, Hänsel M, Hamel W, Kunzmann R and Hölzel F: Karyotype analyses of 20 human glioma cell lines. Acta Neurochir 126: 17-26, 1994

32. Wiltshire RN, Rasheed BK, Friedman HS, Friedman AH and Bigner SH: Comparative genetic patterns of glioblastoma multiforme: potential diagnostic tool for tumor classification. Neuro Oncol 2: 164-173, 2000.

33. Mao X and Hamoudi RA: Molecular and cytogenetic analysis of glioblastoma multiforme. Cancer Genet Cytogenet 122: 87-92, 2000.

34. Dahlback HS, Brandal P, Meling TR, Gorunova L, Scheie D and Heim S: Genomic aberrations in 80 cases of primary glioblastoma multiforme: Pathogenetic heterogeneity and putative cytogenetic pathways. Genes Chromosomes Cancer 48: 908-924, 2009.

35. Gisselsson D, Håkanson U, Stoller P, Marti D, Jin Y, Rosengren AH, Stewénius Y, Kahl F and Panagopoulos I: When the genome plays dice: circumvention of the spindle assembly checkpoint and near-random chromosome segregation in multipolar cancer cell mitoses. PLoS One 3: e1871, 2008.

36. Shaffer LG, Slovak ML, Campbell LJ (eds). International System of Human Cytogenetic Nomenclature. S. Karger AG, Basel, 2013. 